\title{
GENETIC VARIABILITY AND SELECTION OF EXTRA-EARLY COWPEA PROGENIES $^{1}$
}

\author{
ANTÔNIO MOREIRA BARROSO NETO $2 *$, RENATA FERNANDES DE MATOS ${ }^{2}$, MARCELO DE SOUSA \\ PINHEIRO ${ }^{2}$, CÂNDIDA HERMÍNIA CAMPOS DE MAGALHÃES BERTINI ${ }^{2}$, JÚLIO CÉSAR DOVALE ${ }^{2}$
}

\begin{abstract}
The precocity of cowpea is important because it indicates the possibility of increasing and/or stabilizing production in regions with long periods of drought. The aim of this study was to evaluate genetic variability and select extra-early cowpea progenies. Fifteen $\mathrm{F}_{3: 6}$ progenies were evaluated in 2014 while sixty-two $\mathrm{F}_{7}$ progenies were evaluated in 2015. Two commercial cultivars were used in experiments performed in the irrigated perimeter of Baixo Acaraú, in Marco, CE. The following characteristics were evaluated: number of days for flowering (NDF), number of days for maturity (NDM), plant height (PH), pod length (PL), number of seeds per pod (NSP), number of grains per plant (NGP), weight of 100 grains $\left(\mathrm{W}_{100} \mathrm{G}\right)$ and total weight $\left(\mathrm{M}_{\mathrm{TOT}}\right)$. Data were analyzed in lattice and $\mathrm{RBD}$, according to the methodology of mixed models by the REML/BLUP procedure. Also, the components of variance and genetic values were estimated. Variability among progenies, high heritability and high accuracy were identified for all traits. For NDF and NDM, the progenies presented higher behavior than the controls. The lattice arrangement contributed to a greater gain

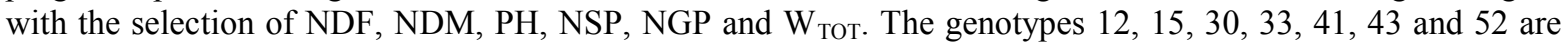
among the top ten because they have high genetic values in three or more traits. The genotypes $12,15,30,33$, 43 and 52 highlight extra-earliness (precocity).
\end{abstract}

Keywords: Vigna unguiculata. Selective accuracy. Mixed model. REML / BLUP.

\section{VARIABILIDADE GENÉTICA E SELEÇÃO DE PROGÊNIES DE FEIJÃO-CAUPI EXTRAPRECOCES}

RESUMO - A precocidade é importante para o feijão-caupi por representar a possibilidade de aumentar e/ou estabilizar a produção em regiões com longos períodos de estiagem. Objetivou- se avaliar a variabilidade genética e selecionar progênies de feijão-caupi extraprecoces. Foram avaliadas 15 progênies $F_{3: 6} \mathrm{em} 2014 \mathrm{e}$ 62 progênies $\mathrm{F}_{7}$ em 2015, juntamente com duas cultivares comerciais em experimentos conduzidos no perímetro irrigado Baixo Acaraú, localizado no município de Marco, CE. Foram avaliados os caracteres: número de dias para o florescimento (NDF), número de dias para a maturação (NDM), altura de planta (ALT), comprimento de vagem (CPV), número de grãos por vagem (NGV), número de grãos por planta (NGP), massa de 100 grãos $\left(\mathrm{M}_{100} \mathrm{G}\right)$ e massa total $\left(\mathrm{M}_{\mathrm{TOT}}\right)$. Os dados foram analisados em DBIL e DBC, segundo a metodologia de modelos mistos, via procedimento REML/BLUP. Foram estimados os componentes de variância e os valores genéticos. Identificou-se variabilidade entre as progênies, alta herdabilidade e elevada acurácia em todos os caracteres avaliados. As progênies apresentaram comportamento superior às testemunhas para NDF e NDM. O arranjo em látice apresentou maior eficiência que o DBC, pelo maior ganho obtido com a seleção nos caracteres NDF, NDM, ALT, NGV, NGP е $\mathrm{M}_{\text {Tот }}$. Os genótipos 12, 15, 30, 33, 41, 43 е 52 encontram-se entre os dez superiores, por apresentarem valores genéticos elevados em três ou mais caracteres. Os genótipos 12, 15, 30, 33, 43 e 52 destacam-se como os mais precoces.

Palavras-chave: Vigna unguiculata. Acurácia seletiva. Modelos Mistos. REML/BLUP.

\footnotetext{
*Corresponding author

${ }^{1}$ Received for publication in $08 / 21 / 2016$; accepted in $12 / 02 / 2016$.

Paper approved from IV CONAC 2016.

Extracted from the first author's dissertation, funded by CNPq.

${ }^{2}$ Center of Agricultural Sciences, Universidade Federal do Ceará, Fortaleza, CE, Brazil; ambnetonet@yahoo.com.br, renatafmatos@hotmail.com, marcelospufc@gmail.com, candida_bertini@yahoo.com.br, juliocvale@gmail.com.
} 


\section{INTRODUCTION}

Cowpea (Vigna unguiculata (L.) Walp.) has great genetic variability that makes it versatile; hence, it is used for several purposes and production systems. Currently, Brazil is the third largest producer in the world, and cowpea is mainly cultivated in the North, Northeast and Central West regions of the country (BEZERRA et al., 2010).

The largest cowpea production $(87.32 \%)$ takes place in the Northeast and accounts for $97.47 \%$ of the cowpea cultivated area in the country. In this region, cowpea has favorable ecological conditions for its development, becoming one of the most important sources of protein in the diet of rural and urban populations. In the Central-West, this culture has been highlighted by the possibility of a second harvest, being a new option for productive arrangements and diversification of the agribusiness of this region (DAMASCENO-SILVA, 2011).

The different productive arrangements require cultivars with different characteristics for the maturation cycle, plant size, grain yield and resistance to pests and diseases. Thus, precocity (early maturation) is one of the main objectives of crop improvement, since it makes it possible to perform up to three cycles per year, using dry farming and irrigated crops (FREIRE FILHO, 2011; OLIVEIRA et al., 2016).

In order to minimize losses from summer crops, cowpea farmers have selected and developed extra-early maturing cultivars, which minimize losses and/or stabilize the production in regions with long periods of drought (MACHADO et al., 2008; AYO-VAUGHAN et al., 2011). Therefore, it is necessary to understand the genetic components that influence precocity in cowpea, because it would help in the development of strategies to improve grain yield and the adaptation of cultivars to stressful environments (ISHIYAKU-SINGH; CRAUFURD et al., 2005).

In recent years, the cultivation of cowpea has expanded to the Cerrado biome of the Brazilian Central-West, where it has been incorporated into the productive arrangements of the second harvest after soybean, rice or corn (FREIRE FILHO, 2011). In these arrangements, cowpea is cultivated after the middle of the rainy season, when there is no expectation of precipitation that may allow the cultivation of a second crop. In this context, there is a small gap of planting for farmers interested in growing cowpea, in which cultivars of early and semi-early cycles fit perfectly, since they last from 60 to 80 days. Thus, an alternative to enlarge the planting gap for cowpea would be the use of extra-early cultivars, with cycles of less than 60 days (OLIVEIRA et al., 2016).

It is estimated that about six or seven genes are involved in the expression of cowpea precocity, indicating its polygenic nature. Since it is a quantitative trait, there is great environmental influence on its expression, which makes it difficult to select superior genotypes (ADEYANJU; ISHIYAKU, 2007; AYO-VAUGHAN et al., 2011).

According to Piepho et al. (2008), the development and recommendation of new varieties require a selection that must be made among a larger group of candidate genotypes, so the estimation of genetic values should be the focus of any effort in this direction.

To overcome these difficulties, in the selection of quantitative traits, the breeder uses genetic-statistical tools capable of isolating only the genotypic components, and predicting real genetic values in the selection. The methods based on BLUP (Best Linear Unbiased Prediction) and REML (Restricted Maximum Likelihood Estimation), with mixed models approach, are estimators that present greater accuracy and precision in the selection of genotypes with high genetic value (BORGES et al., 2010).

The aim of this study was to evaluate the efficiency of incomplete blocks with lattice design and randomized complete block design (RCBD) on the estimation of genetic variability and to select extra-early/ extra-precocious cowpea progenies.

\section{MATERIAL AND METHODS}

Fifteen progenies of $\mathrm{F}_{3: 6}$ cowpea were evaluated and a selection was made between and within these progenies, resulting in sixty-two $\mathrm{F}_{7}$ progenies, which were evaluated in 2015. These progenies originate from the Embrapa Meio Norte Cowpea Breeding Program, Teresina-PI, and were obtained from diallel crosses between the genitors IT82D-889, AU94MOB-816, IT82D-60, MNC04- 789B-119-2-3-1 and MNC05-820B-240 and selected by the Bulk method within and between families, by Oliveira et al. (2016).

$F_{3: 6}$ progenies were evaluated in 2014 in a RCBD with three replications. Two commercial cultivars (BRS Tumucumaque and Sempre Verde) were used as controls. The plot was composed by a line of $4.5 \mathrm{~m}$ and by 18 plants, with spacing of $1.00 \mathrm{~m}$ between plots and $0.25 \mathrm{~m}$ between holes within the line. The usable area was represented by the 16 central plants of the plot.

$\mathrm{F}_{7}$ progenies were obtained from the selection in progenies $\mathrm{F}_{3: 6}$, using an intensity of $10 \%$. In 2015 , they were evaluated using an incomplete blocks design, with an $8 \times 8$ square lattice arrangement, using two replications as a result of the low seed quantity. The treatments consisted of 62 progenies and two controls, represented by two commercial cultivars (BRS Tumucumaque and Sempre Verde), totalling 64 treatments. The plot contained a row of $4 \mathrm{~m}$, with a total of 17 holes per plot, with $1 \mathrm{~m}$ between plots and plants within the row of $0.25 \mathrm{~m}$. The utilized 
area was represented by 16 central plants of the plot.

In both tests, a single-bed was fertilized with superphosphate $(40 \mathrm{~kg} / \mathrm{ha})$ and potassium chloride (20 kg / ha) according to soil analysis $(6.0 \mathrm{mg} / \mathrm{kg}$ phosphorus and $0.15 \mathrm{cmol} / \mathrm{kg}$ potassium). After fifteen days of sowing, thinning was performed, leaving one plant per hole. After twenty days of sowing, cover fertilization with urea (30 kg / ha) was performed, following the recommendations for the crop. The cultivation was carried out in an irrigated system by using a micro sprinkler, with irrigation shift of five days on average, for two hours.

The traits evaluated in both trials were: number of days for flowering (NDF), number of days for maturity (NDM), plant height $(\mathrm{PH})$, pod length (PL), number of seeds per pod (NSP), number of grains per plant (NGP), weight of 100 dry grains $\left(\mathrm{W}_{100} \mathrm{G}\right)$ and total production of dry grains $\left(\mathrm{W}_{\mathrm{TOT}}\right)$.

After evaluating all traits, an index which resulted from an adaptation of the selection method of Pesek and Baker (1969) was adopted. According to the objectives of the program, for each character, a different weight was attributed with proper specification of the desired gains. Precocity, grain weight and plant height were included in the index. Thus, for each character, weights 1,2 and 3 were attributed, respectively. The index was composed of the sum of the weights of all traits for each progeny, establishing precocity (evaluated by the number of days for flowering and pod maturation) as a priority, followed by the other traits in order of importance.

Data were submitted for statistical analysis using the methodology of mixed models, by the REML/BLUP procedure, using the likelihood ratio test (LRT), according to Resende (2002).

\section{RESULTS AND DISCUSSION}

According to the results of the experiment conducted in 2015, for data from the randomized block design (RBD), the effect was only for the number of days for flowering (NDF) and number of days for maturation (NDM). This shows that there was a difference between the phenotypic values of these traits at the blocks level, which indicates the existence of environmental variability due to the heterogeneity of the experimental area.

On analyzing the data according to the lattice arrangement, most of the characters evaluated presented a significant difference for the effects of repetitions and blocks. For the effect of repetitions, a significant difference was verified only in NDF and NDM.

Regarding the effect of blocks within replications, the test found a significant difference for plant height $(\mathrm{PH})$, pod length (PL), number of grains per plant (NGP) and total weight $\left(\mathrm{W}_{\mathrm{TOT}}\right)$, which were not significant when data were analyzed according to the complete randomized block design.
In addition, there was a difference regarding the experimental error when both designs were compared. The lattice arrangement provided a reduction in experimental error, justifying the choice of this design over the complete randomized block. This is because the lattice arrangement separates a component from the experimental error due to the variance of repetitions effect, thereby increasing the experimental accuracy. This separation was not possible in the RCBD because the blocks were assembled in repetitions, not allowing to calculate an estimate of the error with the separation of the component due to the effect of repetitions (RAMALHO; FERREIRA; OLIVEIRA et al., 2012).

Another fact that justifies the choice of lattice design is the number of progenies evaluated in this work, since it is a matter of evaluating characters with quantitative inheritance (controlled by several genes), there is a need of evaluating a large number of progenies. This impairs the efficiency of the RCBD, due to the heterogeneity of the area to shelter blocks containing all the progenies to be evaluated (SILVA et al., 1999; RAMALHO; FERREIRA; OLIVEIRA et al., 2012)

Silva et al. (1999) and Regazzi et al. (1999) studied the advantages of the lattice experimental design in the evaluation of corn hybrids, and observed that for most evaluated environments, the lattice was superior to RBD. For Cruzio (2014), who worked with 97 progenies of cowpea, the lattice provided greater efficiency when compared to the block design. According to the authors, the main advantage of the lattice was the reduction of experimental error, being a good alternative to minimize the effects of environmental heterogeneity when the number of treatments or the size of the plots are very large.

The results of the aforementioned authors corroborate with the present study, regarding the reduction of experimental error presented in the table of deviance analysis (Table 1). It was observed that the use of a lattice provided a higher efficiency for all evaluated traits, except for the weight of 100-grains $\left(\mathrm{W}_{100}\right)$ which was $100 \%$. Ramalho, Ferreira and Oliveira et al. (2012) stated that when this efficiency is less than 100 , it is recommended to despise the lattice analysis and to have the experiment analyzed in complete randomized blocks.

In the present study, the efficiency of the lattice slightly exceeded the threshold of $100 \%$, thereby justifying the choice of this design. However, since the selection of cowpea has a high degree of endogamy, with $\mathrm{F}_{7}$ progenies, this efficiency (although very small) can directly contribute to the conduction of a final selection with greater effectiveness. This efficiency is probably due to the fact that this type of design captures information of possible intrablock variability, not adding them to the experimental error as a non-explainable factor. 
Some studies with cowpea have reported the efficiency of the lattice over RBD. Rodrigues et al. (2016) evaluated drought tolerance in cowpea genotypes in a lattice design and obtained an efficiency of over $100 \%$ for most of the evaluated traits, including the number of days for flowering and maturation, with efficiencies of $120.55 \%$ and $125.23 \%$, respectively.

In both designs, for the genotype effect, a differential behavior was verified in all evaluated traits, evidenced by the Likelihood Ratio Test (LRT). These results confirm that due to the existing genetic variability, it is possible to identify superior genotypes, allowing selection among them for the development of future cultivars, as cited by Torres et al. (2015) and Oliveira et al. (2016). According to Correa et al. (2012), the significance of the effects of genotypes contributes to the selection success, since this is influenced by genetic variance. For Krause, Rodrigues and Leal et al. (2012), the significance of the effect of genotypes on the great majority of traits, indicates the existence of variability, resulting from the action of additive and non-additive gene effects in the control of the evaluated characters.

These effects were identified by Ishiyaku; Singh and Craufurd et al. (2005) and Ayo-Vaughan et al. (2011), when studying and controlling precocity in cowpea. For these authors, both additive and non-additive effects control earliness (precocity). The additive effects are the most important because they are inheritable in nature. For selection purposes, the interest is in the additive genetic value, which is the sum of the effects of the alleles at the locus that controls the quantitative character under selection (NDF and NDM).
The significance of the effect of the genotypes reveals the existence of variability in the progenies of the present study. Thus, it has become necessary to know the origin of this variability (environmental or genetic), its portion can contribute to the selection process, being necessary to understand and estimate its real values and proportions. Using estimates of the variance and heritability components at the mean level of genotypes obtained by the REML / BLUP methods, in both designs (Table 2), it was verified that all traits presented a high magnitude of heritability, except for $\mathrm{PH}$ in the RBD, according to the classification proposed by Resende (2002). All other characters presented a high magnitude of heritability (above 0.5), showing that most of the presented variability can be explained by genotypic variation

The high heritability observed for all evaluated traits is explained by the advanced stage of the genotypes $\left(\mathrm{F}_{7}\right)$, with a high degree of homozygosity, as verified by Rocha et al. (2009) and Barros et al. (2011). The same results were obtained by Ishiyaku; Singh and Craufurd et al. (2005), for NDF and NDM in cowpea, with heritability restricted to 0.86 .

These heritability values can be justified by genotypic variance, which confirms the existence of genetic variability among them. According to Garcia and Nogueira (2005), Rosado et al. (2012), Sousa (2015) and Torres et al. (2015), high estimates of heritability coefficient show evidence that the genetic component presents high expression in the phenotype, showing great potential for selection and good perspectives of genetic gain.

Table 1. Deviance analysis considering the randomized block designs and the square lattice for the number of days for flowering (NDF), number of days for maturity (NDM), plant height (PH), pod length (PL), Number of seeds per pod (NSP), number of grains per plant (NGP), weight of 100 grains $\left(\mathrm{W}_{100} \mathrm{G}\right)$ and total weight $\left(\mathrm{W}_{\mathrm{TOT}}\right)$ evaluated in 62 genotypes derived from $\mathrm{F}_{7}$ progenies of cowpea and two commercial controls.

\begin{tabular}{|c|c|c|c|c|c|c|c|c|c|}
\hline \multirow{2}{*}{ Analysis } & \multirow{2}{*}{ Effect } & \multicolumn{8}{|c|}{ Character } \\
\hline & & NDF & NDM & $\mathrm{PH}$ & PL & NSP & NGP & $\mathrm{W}_{100} \mathrm{G}$ & $\mathrm{W}_{\text {ТОТ }}$ \\
\hline \multirow{3}{*}{ RBD } & Blocks $^{1}$ & $11.453^{+++}$ & $11.003^{+++}$ & $0.842^{\text {ns }}$ & $0.804^{\mathrm{ns}}$ & $0.173^{\mathrm{ns}}$ & $2.182^{\mathrm{ns}}$ & $2.091^{\mathrm{ns}}$ & $0.221^{\mathrm{ns}}$ \\
\hline & Gentypes $^{2}$ & $10.565^{* * *}$ & $22.453^{* * *}$ & $5.896^{* *}$ & $37.881^{* * *}$ & $33.642^{* * *}$ & $12.393^{* * *}$ & $72.920^{* * *}$ & $13.205^{* * *}$ \\
\hline & Error & 6.697 & 2.125 & 19.856 & 1.241 & 1.678 & 1383.550 & 1.276 & 34.424 \\
\hline \multirow{4}{*}{ Lattice } & Replicates 1 & $10.132^{++}$ & $10.023^{++}$ & $0.254^{\mathrm{ns}}$ & $0.303^{\mathrm{ns}}$ & $0.152^{\mathrm{ns}}$ & $0.643^{\mathrm{ns}}$ & $2.091^{\mathrm{ns}}$ & $0.054^{\mathrm{ns}}$ \\
\hline & Blocks/Rep ${ }^{2}$ & $2.70 \times 10^{-7 \mathrm{~ns}}$ & $0.017^{\mathrm{ns}}$ & $11.926^{* * *}$ & $7.336^{* * *}$ & $5.04 \times 10^{-6 \mathrm{~ns}}$ & $8.037^{* * *}$ & $4.17 \times 10^{-6 \mathrm{~ns}}$ & $12.570^{* * *}$ \\
\hline & Genotypes $^{2}$ & $10.637^{* * *}$ & $22.470^{* * *}$ & $8.219^{* * *}$ & $33.973^{* * *}$ & $33.682^{* * *}$ & $17.161^{* * *}$ & $72.920^{* * *}$ & $20.322^{* * *}$ \\
\hline & Error & 6.550 & 2.095 & 13.556 & 1.087 & 1.648 & 961.135 & 1.276 & 20.569 \\
\hline \multirow{2}{*}{$\begin{array}{l}\text { RBD } \\
v s . \text { Lattice }\end{array}$} & Contrast $^{2}$ & $0.071^{\mathrm{ns}}$ & $0.034^{\mathrm{ns}}$ & $14.249^{* * *}$ & $3.427^{*}$ & $0.039^{\mathrm{ns}}$ & $12.806^{* * *}$ & $1.667^{\mathrm{ns}}$ & $19.647^{* * *}$ \\
\hline & Efficiency & 1.022 & 1.014 & 1.465 & 1.142 & 1.018 & 1.439 & 1.000 & 1.674 \\
\hline
\end{tabular}

${ }^{1}$ Wald F Statistic; ${ }^{+++}$significant at $1 \%$ of probability; ${ }^{\text {ns }}$ non-significant.

${ }^{2}$ Likelihood Ratio Test (LRT), tested by chi-square with 1 as degree of freedom; ***significant at $1 \%$ of probability;

**significant at $5 \%$ of probability; ${ }^{\text {ns }}$ non-significant. 
Based on the selection made in $\mathrm{F}_{3: 6}$ progenies, the gain obtained with the selection in NDF, NDM and $\mathrm{PH}$ was negative. This was explained by the purpose of the program in reducing the expression of these traits (precocity). In general, the gain with the selection varied from -3.611 to $72.721 \%$ and -3.598 to $65.236 \%$, for lattice and $\mathrm{RBD}$, respectively. The lowest values were for NDF and NDM, in both designs. For the lattice, the values were: $-4.764 \%$ and $-3.611 \%$, and for RBD, $-4.757 \%$ and $-3.598 \%$; respectively. Although the gains with selection are small, they are of great relevance, when compared with the other traits, considering the high degree of endogamy and genotypes selection.

The estimates for gain with selection were higher in the lattice design. However, for all traits, the relationship between selection gains in both designs was close to one unit, showing that the designs were matched for GS. This fact is explained by the essence of lattice, which separates from the experimental error another factor of variation, explaining the environmental variability existing in the block within the repetition. These values directly influence the experimental accuracy, indicating that the lattice was superior to RBD.

By observing the results of the lattice accuracy, it can be seen that all the traits showed an accuracy above 0.5 . The highlights were: pod length (PL), number of seeds per pod (NSP), and $\mathrm{W}_{100} \mathrm{G}$, which presented a high accuracy (close to one), implying directly that the selection process is efficient.

This higher predictive accuracy for PL, NGV and $\mathrm{W}_{100} \mathrm{G}$ is due to the fact that random effects predictions are forced towards the overall mean (shrinkage), eliminating the residual environmental effects that are embedded in the phenotypic data and correcting the phenotypic value in function of the heritability of the character under selection. It does not happen when the effects are considered fixed. According to Viana et al. (2010) and Pinheiro et al. (2013), with this adjustment of the phenotypic values by heritability, it is concluded that the higher the adjusted heritability, the lower the shrinkage, the greater the selective accuracy and the greater the genetic gain.

For Pimentel et al. (2014) and Torres et al. (2015), high accuracy values showed good experimental quality, indicating an excellent relationship between the predicted and real values, which results in selection safety. These high values of accuracy in all characters can be justified by the efficiency of the mixed models and REML/BLUP predictors. These predictors are efficient in estimating the components of variance and genetic values, since they aid in the estimation of genetic values based on the unfolding of phenotypic variation in various genetic components (BALDISSERA et al., 2012; RESENDE et al., 2014).

Table 2. Estimates of genotypic and block variances within the replicate, heritability at the level of means, gains with selection (in absolute terms and percentage), and accuracy of the selection process, considering the randomized block designs and the square lattice for the number of days for flowering (NDF), number of days for maturity (NDM), plant height $(\mathrm{PH})$, pod length (PL), Number of seeds per pod (NSP), number of grains per plant (NGP), weight of 100 grains $\left(\mathrm{W}_{100} \mathrm{G}\right)$ and total weight $\left(\mathrm{W}_{\text {TOT }}\right)$ evaluated in 62 genotypes derived from $\mathrm{F}_{7}$ progenies of cowpea and two commercial controls.

\begin{tabular}{|c|c|c|c|c|c|c|c|c|c|}
\hline \multirow{2}{*}{ Design } & \multirow{2}{*}{ Parameters } & \multicolumn{8}{|c|}{ Characters } \\
\hline & & $\mathrm{NDF}$ & NDM & $\mathrm{PH}$ & PL & NSP & NGP & $\mathrm{W}_{100} \mathrm{G}$ & $\mathrm{W}_{\text {ТОт }}$ \\
\hline \multirow{5}{*}{ RBD } & $\hat{\sigma}_{g}^{2}$ & 4.335 & 2.571 & 8.465 & 2.545 & 3.025 & 1012.483 & 6.146 & 26.487 \\
\hline & $h_{m}^{2}$ & 0.564 & 0.708 & 0.460 & 0.804 & 0.783 & 0.594 & 0.906 & 0.606 \\
\hline & GS & -1.615 & -1.778 & -2.871 & 2.800 & 2.983 & 58.365 & 4.878 & 9.154 \\
\hline & GS(\%) & -4.757 & -3.598 & -11.745 & 16.730 & 25.884 & 61.431 & 33.824 & 65.236 \\
\hline & Accuracy & 0.675 & 0.863 & 0.516 & 0.945 & 0.931 & 0.719 & 0.989 & 0.736 \\
\hline \multirow{6}{*}{ Lattice } & $\hat{\sigma}_{b / r}^{2}$ & 0.133 & 0.032 & 6.576 & 0.226 & 0.029 & 465.905 & $7.42 \times 10^{-7}$ & 15.029 \\
\hline & $\hat{\sigma}_{g}^{2}$ & 4.383 & 2.575 & 9.231 & 2.397 & 3.036 & 1029.628 & 6.146 & 27.649 \\
\hline & $h_{m}^{2}$ & 0.572 & 0.711 & 0.577 & 0.815 & 0.787 & 0.682 & 0.906 & 0.729 \\
\hline & GS & -1.617 & -1.785 & -3.332 & 2.704 & 2.992 & 62.995 & 4.878 & 10.204 \\
\hline & GS(\%) & -4.764 & -3.611 & -13.629 & 16.154 & 25.963 & 66.306 & 33.824 & 72.721 \\
\hline & Accuracy & 0.687 & 0.867 & 0.694 & 0.952 & 0.934 & 0.835 & 0.989 & 0.885 \\
\hline $\begin{array}{c}\text { RBD } \\
v s . \text { Lattice }\end{array}$ & $\mathrm{R}$ & 0.998 & 0.999 & 0.940 & 0.993 & 0.999 & 0.956 & 1.000 & 0.938 \\
\hline
\end{tabular}


This selective accuracy reflects the quality of the information of the procedures used in the prediction of genetic values. It is also associated with the precision of the selection based on predicted genetic values which are more reliable, with inferences about genotype means and non phenotype means. This helps in determining the reliability of how accurate the "ranking" of cowpea genotypes will be (PIMENTEL et al., 2014).

The genotypic values of the characters in the 62 progenies are presented in Tables 3 and 4. The lowest estimates were observed in NDF, NDM and PH (Table 3). Values lower than at least one of the controls (BRS Tumucumaque and Sempre Verde), showed that all these progenies may be the basis for future breeding programs aimed at earliness (precocity), for presenting extra-early cycle plants, according to Freire Filho (2011). This is in addition to composing future programs which are aimed at reducing the size of plants.

Table 3. Genotypic values for number of days for flowering (NDF), number of days for maturity (NDM), plant height (PH), pod length (PL), considering the randomized block designs and the square lattice evaluated in 62 genotypes derived from $\mathrm{F}_{7}$ progenies of cowpea and two commercial controls.

\begin{tabular}{|c|c|c|c|c|c|c|c|c|}
\hline \multirow{2}{*}{ Progenies } & \multicolumn{2}{|c|}{ NSP } & \multicolumn{2}{|c|}{ NGP } & \multicolumn{2}{|c|}{$\mathrm{W}_{100} \mathrm{G}$} & \multicolumn{2}{|c|}{$\mathrm{W}_{\text {TOT }}$} \\
\hline & RBD & Lattice & RBD & Lattice & RBD & Lattice & RBD & Lattice \\
\hline 1 & 11.897 & 11.868 & 92.330 & 96.006 & 14.097 & 14.097 & 12.805 & 13.764 \\
\hline 2 & 12.679 & 12.649 & 110.747 & 118.911 & 15.100 & 15.100 & 16.525 & 18.279 \\
\hline 3 & 14.245 & 14.203 & 187.384 & 190.477 & 12.140 & 12.140 & 25.266 & 25.363 \\
\hline 4 & 10.722 & 10.666 & 102.726 & 104.334 & 15.194 & 15.194 & 15.956 & 16.711 \\
\hline 5 & 11.505 & 11.506 & 91.142 & 102.237 & 12.636 & 12.636 & 13.009 & 15.059 \\
\hline 6 & 10.331 & 10.274 & 115.202 & 113.257 & 18.103 & 18.103 & 19.171 & 18.899 \\
\hline 7 & 11.114 & 11.087 & 73.913 & 73.448 & 13.761 & 13.761 & 10.374 & 10.368 \\
\hline 8 & 9.548 & 9.510 & 88.765 & 87.948 & 14.518 & 14.518 & 13.469 & 13.416 \\
\hline 9 & 10.722 & 10.748 & 111.341 & 113.374 & 16.194 & 16.194 & 17.072 & 17.915 \\
\hline 10 & 10.918 & 10.939 & 71.537 & 69.464 & 18.456 & 18.456 & 11.276 & 10.987 \\
\hline 11 & 11.114 & 11.117 & 104.806 & 91.260 & 17.910 & 17.910 & 19.639 & 17.616 \\
\hline 12 & 12.288 & 12.299 & 105.400 & 102.953 & 11.760 & 11.760 & 12.992 & 12.166 \\
\hline 13 & 10.722 & 10.780 & 94.409 & 101.537 & 14.303 & 14.303 & 14.199 & 15.510 \\
\hline 14 & 11.505 & 11.513 & 107.776 & 100.285 & 16.300 & 16.300 & 17.127 & 15.461 \\
\hline 15 & 11.505 & 11.540 & 101.538 & 100.702 & 12.977 & 12.977 & 14.499 & 14.347 \\
\hline 16 & 11.505 & 11.536 & 83.715 & 77.703 & 13.177 & 13.177 & 11.269 & 9.790 \\
\hline 17 & 8.765 & 8.753 & 77.478 & 66.769 & 13.805 & 13.805 & 11.336 & 9.588 \\
\hline 18 & 11.505 & 11.501 & 104.806 & 99.900 & 18.412 & 18.412 & 20.511 & 20.663 \\
\hline 19 & 10.331 & 10.302 & 93.518 & 70.562 & 16.709 & 16.709 & 15.841 & 11.620 \\
\hline 20 & 11.505 & 11.484 & 90.548 & 78.165 & 12.038 & 12.038 & 12.068 & 9.626 \\
\hline 21 & 10.331 & 10.358 & 83.715 & 81.521 & 11.633 & 11.633 & 10.172 & 9.237 \\
\hline 22 & 10.918 & 10.895 & 96.785 & 79.928 & 15.136 & 15.136 & 14.476 & 10.844 \\
\hline 23 & 14.245 & 14.265 & 185.602 & 189.431 & 12.619 & 12.619 & 23.284 & 23.482 \\
\hline 24 & 11.309 & 11.311 & 101.538 & 90.413 & 10.345 & 10.345 & 12.102 & 9.363 \\
\hline 25 & 11.505 & 11.506 & 73.022 & 74.884 & 12.341 & 12.341 & 9.544 & 9.797 \\
\hline 26 & 10.526 & 10.518 & 69.754 & 72.903 & 14.281 & 14.281 & 10.405 & 10.876 \\
\hline 27 & 12.092 & 12.071 & 89.953 & 79.700 & 12.488 & 12.488 & 11.458 & 8.714 \\
\hline 28 & 11.505 & 11.484 & 88.765 & 89.348 & 15.447 & 15.447 & 13.195 & 13.346 \\
\hline 29 & 11.114 & 11.144 & 84.607 & 95.773 & 15.951 & 15.951 & 13.385 & 15.466 \\
\hline 30 & 9.548 & 9.518 & 84.013 & 78.498 & 14.597 & 14.597 & 11.720 & 9.894 \\
\hline 31 & 15.420 & 15.444 & 124.114 & 132.094 & 11.657 & 11.657 & 15.407 & 16.376 \\
\hline 32 & 9.156 & 9.148 & 75.695 & 73.984 & 14.298 & 14.298 & 12.650 & 12.387 \\
\hline 33 & 10.918 & 10.938 & 97.082 & 105.613 & 12.028 & 12.028 & 12.053 & 13.544 \\
\hline 34 & 13.462 & 13.489 & 72.131 & 78.747 & 11.406 & 11.406 & 9.371 & 10.361 \\
\hline 35 & 13.071 & 13.077 & 79.557 & 70.885 & 13.859 & 13.859 & 12.594 & 10.808 \\
\hline 36 & 12.288 & 12.292 & 89.062 & 92.805 & 10.603 & 10.603 & 10.910 & 11.328 \\
\hline 37 & 11.505 & 11.560 & 69.160 & 81.163 & 15.414 & 15.414 & 10.419 & 12.628 \\
\hline 38 & 13.071 & 13.080 & 78.369 & 75.138 & 9.348 & 9.348 & 8.947 & 7.288 \\
\hline 39 & 12.288 & 12.320 & 96.191 & 103.167 & 13.805 & 13.805 & 14.400 & 15.893 \\
\hline 40 & 9.156 & 9.170 & 71.834 & 72.669 & 14.529 & 14.529 & 10.605 & 10.656 \\
\hline 41 & 11.505 & 11.513 & 83.715 & 87.466 & 12.791 & 12.791 & 11.152 & 11.949 \\
\hline 42 & 9.352 & 9.344 & 69.457 & 72.873 & 20.362 & 20.362 & 12.096 & 13.126 \\
\hline 43 & 11.114 & 11.097 & 70.051 & 68.182 & 12.336 & 12.336 & 9.171 & 8.725 \\
\hline 44 & 10.722 & 10.758 & 75.398 & 85.515 & 16.465 & 16.465 & 11.413 & 13.311 \\
\hline 45 & 12.679 & 12.671 & 89.953 & 85.627 & 11.091 & 11.091 & 11.217 & 9.507 \\
\hline 46 & 13.854 & 13.878 & 117.282 & 124.564 & 15.458 & 15.458 & 20.722 & 22.983 \\
\hline 47 & 13.071 & 13.087 & 103.320 & 105.997 & 12.319 & 12.319 & 12.860 & 12.856 \\
\hline
\end{tabular}


Table 3. Continuation.

\begin{tabular}{|c|c|c|c|c|c|c|c|c|}
\hline \multirow{2}{*}{ Progenies } & \multicolumn{2}{|c|}{ NSP } & \multicolumn{2}{|c|}{ NGP } & \multicolumn{2}{|c|}{$\mathrm{W}_{100} \mathrm{G}$} & \multicolumn{2}{|c|}{$\mathrm{W}_{\mathrm{TOT}}$} \\
\hline & RBD & Lattice & RBD & Lattice & RBD & Lattice & RBD & Lattice \\
\hline 48 & 13.071 & 13.094 & 105.103 & 115.965 & 14.224 & 14.224 & 14.856 & 16.998 \\
\hline 49 & 10.722 & 10.729 & 72.428 & 80.236 & 15.090 & 15.090 & 11.159 & 12.594 \\
\hline 50 & 11.505 & 11.496 & 82.527 & 75.442 & 16.220 & 16.220 & 13.141 & 11.550 \\
\hline 51 & 11.897 & 11.892 & 89.062 & 93.953 & 16.227 & 16.227 & 13.700 & 14.765 \\
\hline 52 & 9.352 & 9.389 & 62.922 & 75.152 & 15.768 & 15.768 & 9.717 & 11.868 \\
\hline 53 & 12.679 & 12.679 & 150.551 & 159.123 & 16.743 & 16.743 & 23.441 & 24.802 \\
\hline 54 & 11.505 & 11.526 & 68.566 & 72.612 & 13.985 & 13.985 & 9.955 & 10.632 \\
\hline 55 & 11.897 & 11.915 & 102.132 & 108.588 & 14.213 & 14.213 & 14.537 & 15.468 \\
\hline 56 & 9.939 & 9.919 & 93.221 & 92.507 & 13.910 & 13.910 & 12.959 & 13.378 \\
\hline 57 & 13.071 & 13.040 & 112.232 & 99.709 & 13.101 & 13.101 & 14.640 & 12.012 \\
\hline 58 & 11.505 & 11.469 & 89.359 & 84.472 & 14.042 & 14.042 & 13.200 & 12.826 \\
\hline 59 & 9.939 & 9.950 & 70.348 & 73.852 & 13.801 & 13.801 & 10.524 & 11.498 \\
\hline 60 & 12.288 & 12.257 & 103.320 & 95.099 & 14.094 & 14.094 & 20.275 & 19.655 \\
\hline 61 & 7.199 & 7.171 & 72.725 & 67.563 & 20.575 & 20.575 & 12.808 & 12.723 \\
\hline 62 & 11.897 & 11.886 & 104.212 & 101.152 & 15.365 & 15.365 & 16.583 & 16.589 \\
\hline BRS Tumucumaque & 13.071 & 13.061 & 133.619 & 130.121 & 19.889 & 19.889 & 25.014 & 25.232 \\
\hline Sempre Verde & 15.811 & 15.812 & 138.966 & 146.773 & 15.539 & 15.539 & 21.386 & 23.553 \\
\hline
\end{tabular}

In most of the progenies, the results were lower than the controls for PL (Table 3), NGV, NGP, $\mathrm{W}_{100} \mathrm{G}$ and $\mathrm{W}_{\text {Тот }}$ (Table 4). Ordering the best progenies, ten showed the lowest genotypic values for $\operatorname{NDF}(19,15,12,33,52,37,30,43,41$ and 35); ten for NDM $(52,33,21,16,30,43,22,12,15$ and $25)$; ten for PH $(2,1,36,14,27,20,46,55,62$ and $45)$; eight for PL $(31,41,53,46,27,55,25$ and 30$)$; ten for NSP $(17,26,18,41,48,15,50,59,60$ and $42)$; ten for NGP $(18,40,10,38,46,4,43,26,25$ and 60$)$; ten for $\mathrm{W}_{100} \mathrm{G}(42,58,56,60,48,4,15,13$,
6 and 5$)$ and ten for $\mathrm{W}_{\text {тОт }}(56,61,62,55,8,41,39$ 59,4 and 58).

The means for the number of days for maturation in this study ranged from 47 to 52 days, which are lower than those obtained by Oliveira et al. (2016), who obtained variation from 52 to 56 days, when studying the crosses that gave rise to the progenies evaluated in this work, indicating that, after the advancement of generations inside and between families, the selection was efficient in obtaining extra-early progenies.

Table 4. Genotypic values for Number of seeds per pod (NSP), number of grains per plant (NGP), weight of 100 grains $\left(\mathrm{W}_{100} \mathrm{G}\right)$ and total weight $\left(\mathrm{W}_{\text {ТОт }}\right)$ considering the randomized block designs and the square lattice evaluated in 62 genotypes derived from $\mathrm{F}_{7}$ progenies of cowpea and two commercial controls.

\begin{tabular}{|c|c|c|c|c|c|c|c|c|}
\hline \multirow{2}{*}{ Progenies } & \multicolumn{2}{|c|}{ NSP } & \multicolumn{2}{|c|}{ NGP } & \multicolumn{2}{|c|}{$\mathrm{W}_{100} \mathrm{G}$} & \multicolumn{2}{|c|}{$\mathrm{W}_{\text {TOT }}$} \\
\hline & RBD & Lattice & RBD & Lattice & RBD & Lattice & RBD & Lattice \\
\hline 1 & 11.897 & 11.868 & 92.330 & 96.006 & 14.097 & 14.097 & 12.805 & 13.764 \\
\hline 2 & 12.679 & 12.649 & 110.747 & 118.911 & 15.100 & 15.100 & 16.525 & 18.279 \\
\hline 3 & 14.245 & 14.203 & 187.384 & 190.477 & 12.140 & 12.140 & 25.266 & 25.363 \\
\hline 4 & 10.722 & 10.666 & 102.726 & 104.334 & 15.194 & 15.194 & 15.956 & 16.711 \\
\hline 5 & 11.505 & 11.506 & 91.142 & 102.237 & 12.636 & 12.636 & 13.009 & 15.059 \\
\hline 6 & 10.331 & 10.274 & 115.202 & 113.257 & 18.103 & 18.103 & 19.171 & 18.899 \\
\hline 7 & 11.114 & 11.087 & 73.913 & 73.448 & 13.761 & 13.761 & 10.374 & 10.368 \\
\hline 8 & 9.548 & 9.510 & 88.765 & 87.948 & 14.518 & 14.518 & 13.469 & 13.416 \\
\hline 9 & 10.722 & 10.748 & 111.341 & 113.374 & 16.194 & 16.194 & 17.072 & 17.915 \\
\hline 10 & 10.918 & 10.939 & 71.537 & 69.464 & 18.456 & 18.456 & 11.276 & 10.987 \\
\hline 11 & 11.114 & 11.117 & 104.806 & 91.260 & 17.910 & 17.910 & 19.639 & 17.616 \\
\hline 12 & 12.288 & 12.299 & 105.400 & 102.953 & 11.760 & 11.760 & 12.992 & 12.166 \\
\hline 13 & 10.722 & 10.780 & 94.409 & 101.537 & 14.303 & 14.303 & 14.199 & 15.510 \\
\hline 14 & 11.505 & 11.513 & 107.776 & 100.285 & 16.300 & 16.300 & 17.127 & 15.461 \\
\hline 15 & 11.505 & 11.540 & 101.538 & 100.702 & 12.977 & 12.977 & 14.499 & 14.347 \\
\hline 16 & 11.505 & 11.536 & 83.715 & 77.703 & 13.177 & 13.177 & 11.269 & 9.790 \\
\hline 17 & 8.765 & 8.753 & 77.478 & 66.769 & 13.805 & 13.805 & 11.336 & 9.588 \\
\hline 18 & 11.505 & 11.501 & 104.806 & 99.900 & 18.412 & 18.412 & 20.511 & 20.663 \\
\hline 19 & 10.331 & 10.302 & 93.518 & 70.562 & 16.709 & 16.709 & 15.841 & 11.620 \\
\hline 20 & 11.505 & 11.484 & 90.548 & 78.165 & 12.038 & 12.038 & 12.068 & 9.626 \\
\hline 21 & 10.331 & 10.358 & 83.715 & 81.521 & 11.633 & 11.633 & 10.172 & 9.237 \\
\hline 22 & 10.918 & 10.895 & 96.785 & 79.928 & 15.136 & 15.136 & 14.476 & 10.844 \\
\hline 23 & 14.245 & 14.265 & 185.602 & 189.431 & 12.619 & 12.619 & 23.284 & 23.482 \\
\hline 24 & 11.309 & 11.311 & 101.538 & 90.413 & 10.345 & 10.345 & 12.102 & 9.363 \\
\hline
\end{tabular}


Table 4. Continuation.

\begin{tabular}{|c|c|c|c|c|c|c|c|c|}
\hline \multirow{2}{*}{ Progenies } & \multicolumn{2}{|c|}{ NSP } & \multicolumn{2}{|c|}{ NGP } & \multicolumn{2}{|c|}{$\mathrm{W}_{100} \mathrm{G}$} & \multicolumn{2}{|c|}{$\mathrm{W}_{\mathrm{TOT}}$} \\
\hline & RBD & Lattice & RBD & Lattice & RBD & Lattice & RBD & Lattice \\
\hline 25 & 11.505 & 11.506 & 73.022 & 74.884 & 12.341 & 12.341 & 9.544 & 9.797 \\
\hline 26 & 10.526 & 10.518 & 69.754 & 72.903 & 14.281 & 14.281 & 10.405 & 10.876 \\
\hline 27 & 12.092 & 12.071 & 89.953 & 79.700 & 12.488 & 12.488 & 11.458 & 8.714 \\
\hline 28 & 11.505 & 11.484 & 88.765 & 89.348 & 15.447 & 15.447 & 13.195 & 13.346 \\
\hline 29 & 11.114 & 11.144 & 84.607 & 95.773 & 15.951 & 15.951 & 13.385 & 15.466 \\
\hline 30 & 9.548 & 9.518 & 84.013 & 78.498 & 14.597 & 14.597 & 11.720 & 9.894 \\
\hline 31 & 15.420 & 15.444 & 124.114 & 132.094 & 11.657 & 11.657 & 15.407 & 16.376 \\
\hline 32 & 9.156 & 9.148 & 75.695 & 73.984 & 14.298 & 14.298 & 12.650 & 12.387 \\
\hline 33 & 10.918 & 10.938 & 97.082 & 105.613 & 12.028 & 12.028 & 12.053 & 13.544 \\
\hline 34 & 13.462 & 13.489 & 72.131 & 78.747 & 11.406 & 11.406 & 9.371 & 10.361 \\
\hline 35 & 13.071 & 13.077 & 79.557 & 70.885 & 13.859 & 13.859 & 12.594 & 10.808 \\
\hline 36 & 12.288 & 12.292 & 89.062 & 92.805 & 10.603 & 10.603 & 10.910 & 11.328 \\
\hline 37 & 11.505 & 11.560 & 69.160 & 81.163 & 15.414 & 15.414 & 10.419 & 12.628 \\
\hline 38 & 13.071 & 13.080 & 78.369 & 75.138 & 9.348 & 9.348 & 8.947 & 7.288 \\
\hline 39 & 12.288 & 12.320 & 96.191 & 103.167 & 13.805 & 13.805 & 14.400 & 15.893 \\
\hline 40 & 9.156 & 9.170 & 71.834 & 72.669 & 14.529 & 14.529 & 10.605 & 10.656 \\
\hline 41 & 11.505 & 11.513 & 83.715 & 87.466 & 12.791 & 12.791 & 11.152 & 11.949 \\
\hline 42 & 9.352 & 9.344 & 69.457 & 72.873 & 20.362 & 20.362 & 12.096 & 13.126 \\
\hline 43 & 11.114 & 11.097 & 70.051 & 68.182 & 12.336 & 12.336 & 9.171 & 8.725 \\
\hline 44 & 10.722 & 10.758 & 75.398 & 85.515 & 16.465 & 16.465 & 11.413 & 13.311 \\
\hline 45 & 12.679 & 12.671 & 89.953 & 85.627 & 11.091 & 11.091 & 11.217 & 9.507 \\
\hline 46 & 13.854 & 13.878 & 117.282 & 124.564 & 15.458 & 15.458 & 20.722 & 22.983 \\
\hline 47 & 13.071 & 13.087 & 103.320 & 105.997 & 12.319 & 12.319 & 12.860 & 12.856 \\
\hline 48 & 13.071 & 13.094 & 105.103 & 115.965 & 14.224 & 14.224 & 14.856 & 16.998 \\
\hline 49 & 10.722 & 10.729 & 72.428 & 80.236 & 15.090 & 15.090 & 11.159 & 12.594 \\
\hline 50 & 11.505 & 11.496 & 82.527 & 75.442 & 16.220 & 16.220 & 13.141 & 11.550 \\
\hline 51 & 11.897 & 11.892 & 89.062 & 93.953 & 16.227 & 16.227 & 13.700 & 14.765 \\
\hline 52 & 9.352 & 9.389 & 62.922 & 75.152 & 15.768 & 15.768 & 9.717 & 11.868 \\
\hline 53 & 12.679 & 12.679 & 150.551 & 159.123 & 16.743 & 16.743 & 23.441 & 24.802 \\
\hline 54 & 11.505 & 11.526 & 68.566 & 72.612 & 13.985 & 13.985 & 9.955 & 10.632 \\
\hline 55 & 11.897 & 11.915 & 102.132 & 108.588 & 14.213 & 14.213 & 14.537 & 15.468 \\
\hline 56 & 9.939 & 9.919 & 93.221 & 92.507 & 13.910 & 13.910 & 12.959 & 13.378 \\
\hline 57 & 13.071 & 13.040 & 112.232 & 99.709 & 13.101 & 13.101 & 14.640 & 12.012 \\
\hline 58 & 11.505 & 11.469 & 89.359 & 84.472 & 14.042 & 14.042 & 13.200 & 12.826 \\
\hline 59 & 9.939 & 9.950 & 70.348 & 73.852 & 13.801 & 13.801 & 10.524 & 11.498 \\
\hline 60 & 12.288 & 12.257 & 103.320 & 95.099 & 14.094 & 14.094 & 20.275 & 19.655 \\
\hline 61 & 7.199 & 7.171 & 72.725 & 67.563 & 20.575 & 20.575 & 12.808 & 12.723 \\
\hline 62 & 11.897 & 11.886 & 104.212 & 101.152 & 15.365 & 15.365 & 16.583 & 16.589 \\
\hline \multicolumn{9}{|l|}{$\overline{B R S}$} \\
\hline Tumucumaque & 13.071 & 13.061 & 133.619 & 130.121 & 19.889 & 19.889 & 25.014 & 25.232 \\
\hline Sempre Verde & 15.811 & 15.812 & 138.966 & 146.773 & 15.539 & 15.539 & 21.386 & 23.553 \\
\hline
\end{tabular}

Progenies 12, 15, 30, 33, 41, 43 and 52 are among the top ten for at least three of the eight traits analyzed, being the most indicated for cultivation, because they have the shortest maturation cycle. For the progenies that are not indicated for planting, they may be used as the basis for future cycles of hybridization with the purpose of reducing the size, being capable of providing positive results. Increasing commercial traits, considering that these progenies present small and colorful grains, which are characteristics that are not appreciated by the consumer market.

\section{CONCLUSION}

The number of days for flowering, number of days for maturation, plant height, number of grains per pod, number of grains per plant and total weight presented greater genetic variability and greater gain with the selection. Progenies 12, 15, 30, 33, 41, 43 and 52 are among the top ten because they have high genetic values in three or more traits, while progenies $12,15,30,33,43$ and 52 stand out in relation to extra earliness (precocity).

\section{REFERENCES}

ADEYANJU, A. O.; ISHIYAKU, M. F. Genetic study of earliness in cowpea (Vigna unguiculata L. Walp). International Journal of Plant Breeding and Genetics, New York, v. 64, n. 1, p. 34-37, 2007.

AYO-VAUGHAN, M. A. et al. Diallel analysis of earliness in cowpea. African Crop Science Conference Proceedings, Kampala, v. 10, n. 4, p. $1-4,2011$. 
BALDISSERA, J. N. C. et al. Uso do melhor Preditor Linear Não-Viesado (BLUP) na predição de híbridos em feijão. Bioscience Journal, Uberlândia, v. 28 , n. 3, p. 395-403, 2012.

BARROS, F. R. et al. Potencial genético de progênies de feijão-caupi segregantes quanto ao tipo da inflorescência. Pesquisa Agropecuária Brasileira, Brasília, v. 46, n. 2, p.182-189, 2011.

BEZERRA, A. K. P. et al. Rotação cultural feijão caupi/milho utilizando-se águas de salinidades diferentes. Ciência Rural, Santa Maria, v. 40, n. 5, p. 1075-1082, 2010.

BORGES, V. et al. Seleção de clones de batata-doce pelo procedimento REML/BLUP. Acta Scientiarum Agronomy, Maringá, v. 32, n. 4, p. 643-649, 2010.

CORREA, A. M. et al. Estimativas de parâmetros genéticos e correlações entre caracteres fenológicos e morfoagronômicos em feijão-caupi. Revista Ceres, Viçosa, v. 59, n. 1, p. 88-94, 2012.

CRUZIO, A. S. Eficiência da seleção precoce para tamanho de grão e seu efeito em outros caracteres de feijão-caupi. 2014. 79 f. Dissertação (Mestrado em Genética e Melhoramento) - Universidade Federal do Piauí, Teresina, 2014

DAMASCENO-SILVA, K. J. Estatística da produção de feijão-caupi. 2011. Disponível em: $<$ https://www.agencia.cnptia.embrapa.br/gestor/ feijaocaupi/arvore/

CONTAG01_16_510200683536.htm>. Acesso em: 20 nov. 2014.

FREIRE FILHO, F. R. Feijão-caupi no Brasil: produção, melhoramento genético, avanços e desafios. 1. ed. Teresina, PI: Embrapa Meio-Norte, $2011.84 \mathrm{p}$

GARCIA, C. H.; NOGUEIRA, M. C. S. Utilização da metodologia REML/BLUP na seleção de clones de eucalipto. Scientia Forestalis, Piracicaba, v. 34, n. 68, p.107-112, 2005.

ISHIYAKU, M. F.; SINGH, B. B.; CRAUFURD, P. $\mathrm{Q}$. Inheritance of time to flowering in cowpea (Vigna unguiculata (L.) Walp.). Euphytica, Wageningen, v.142, n. 3, p. 291-300, 2005.

KRAUSE, W.; RODRIGUES, R.; LEAL, N. R. Capacidade combinatória para características agronômicas em feijão de vagem. Ciência Agronômica, Fortaleza, v. 43, n. 3, p. 522-531, 2012.

MACHADO, C. F. et al. Identificação de genótipos de feijão-caupi quanto à precocidade, arquitetura da planta e produtividade de grãos. Revista Ciência Agronômica, Fortaleza, v. 39, n. 1, p.114-123, 2008.

OLIVEIRA, R. M. M. et al. Diallel analysis in cowpea aiming at selection for extra-earliness. Crop Breeding and Applied Biotechnology, Viçosa, v. 16, n. 3, p. 167-173, 2016.

PESEK, J.; BAKER, R. J. Desired improvement in relation to selection indices. Canadian Journal of Plant Science, Ottawa, v. 1, n. 1, p. 215-274, 1969.

PIEPHO, H. P. et al. BLUP for phenotypic selection in plant breeding and variety testing. Euphytica, Wageningen, v. 161, n. 1, p. 209-228, 2008.

PIMENTEL, A. J. B. et al. Estimação de parâmetros genéticos e predição de valor genético aditivo de trigo utilizando modelos mistos. Pesquisa Agropecuária Brasileira, Brasília, v. 49, n. 11, p. 882-890, 2014

PINHEIRO, L. C. M. et al. Parentesco na seleção para produtividade e teores de óleo e proteína em soja via modelos mistos. Pesquisa Agropecuária Brasileira, Brasília, v. 48, n. 9, p. 1246-1253, 2013.

RAMALHO, M. A. P.; FERREIRA, D. F.; OLIVEIRA, A. C. Experimentação em genética e melhoramento de plantas. 2. ed. Lavras, MG: Editora UFLA, 2012. 522 p.

REGAZZI, A. J. et al. Análise de experimentos em látice quadrado com ênfase em componentes de variância. II. Análise conjunta. Pesquisa Agropecuária Brasileira, Brasília, v. 34, n. 11, p. 1987-1997, 1999.

RESENDE, M. D. V. Genética biométrica e estatística no melhoramento de plantas perenes. 1 . ed. Brasília, DF: Embrapa Informação Tecnológica; Colombo: Embrapa Florestas, 2002. 975 p

RESENDE, M. A. V. et al. Divergência genética e índice de seleção via BLUP em acessos de algodoeiro para características tecnológicas da fibra. Pesquisa Agropecuária Tropical, Goiânia, v. 44, n. 3, p. 334-340, 2014.

ROCHA, M. M. et al. Controle genético do comprimento do pedúnculo em feijão-caupi. Pesquisa Agropecuária Brasileira, Brasília, v. 44, n. 3, p. 270-275, 2009.

RODRIGUES, E. V. et al. Diallelic analysis to obtain cowpea populations tolerant to hidric deficit. Genetics and Molecular Research, Ribeirão Preto, v. 15, n. 2 , p. 1-8, 2016 
ROSADO, A. M. et al. Seleção simultânea de clones de eucalipto de acordo com produtividade, estabilidade e adaptabilidade. Pesquisa Agropecuária Brasileira, Brasília, v. 47, n. 7, p. 964-971, 2012.

SILVA, H. D. et al. Análise de experimentos em látice quadrado com ênfase em componentes de variância. I. Análises individuais. Pesquisa Agropecuária Brasileira, Brasília, v. 34, n. 10, p. 1811-1822, 1999.

SOUSA, C. M. B. Seleção de progênies F2 de feijão-vagem para produção via modelos mistos. 2015. 56 f. Dissertação (Mestrado em Genética e Melhoramento de Plantas) - Universidade Estadual do Norte Fluminense Darcy Ribeiro, Campos dos Goytacazes, 2015.

TORRES, F. E. et al. Número de repetições para avaliação de caracteres em genótipos de feijão-caupi. Bragantia, Campinas, v. 74, n. 2, p. 161-168, 2015.

VIANA, J. M. S. et al. Multi-trait BLUP in half-sib selection of annual crops. Plant Breeding, Bonn, v. 129, n. 6, p. 599-604, 2010. 